\title{
The Social Place of the Portuguese Punk Scene: an Itinerary of the Social Profiles of its Protagonists
}

La position sociale de la scène punk portugaise : un itinéraire des profils sociaux de ses protagonistes

Paula Abreu, Augusto Santos Silva, Paula Guerra, Ana Oliveira and Tânia Moreira

\section{(2) OpenEdition}

\section{Journals}

Electronic version

URL: https://journals.openedition.org/volume/5386

DOI: $10.4000 /$ volume.5386

ISSN: 1950-568X

\section{Publisher}

Association Mélanie Seteun

\section{Printed version}

Date of publication: 13 December 2017

Number of pages: 103-126

ISBN: 978-2-913169-43-2

ISSN: 1634-5495

\section{Electronic reference}

Paula Abreu, Augusto Santos Silva, Paula Guerra, Ana Oliveira and Tânia Moreira, "The Social Place of the Portuguese Punk Scene: an Itinerary of the Social Profiles of its Protagonists", Volume! [Online], 14 : 1 | 2017, Online since 13 December 2020, connection on 24 March 2023. URL: http:// journals.openedition.org/volume/5386 ; DOI: https://doi.org/10.4000/volume.5386 


\section{Article}

\section{The Social Place of Portuguese Punk Scene: \\ An Itinerary of the Social Profiles of Its Protagonists}

\section{Par Paula Abreu (University of Coimbra), Augusto Santos Silva (University of Porto), Paula Guerra (University of Porto), Ana Oliveira (Dinâmia'CET-IUL) \& Tânia Moreira (University of Porto)}

\footnotetext{
Abstract: This article will present a characterisation of the Portuguese punk scene between 1977 and 2014, while considering the social profiles of its protagonists. It is based on the sociological principle that the social positioning of social actors involved influences what they do, say, and feel. Their social profiling will help clarify their role in the musical scene. This approach has been deemed fundamental in interpreting youth cultures emerging post-war and the way in which they re-equated pop culture. In this article, we have two particular aims: first, establishing a portrait of the leading characters in the Portuguese punk scene through the social profiling of 214 individuals interviewed between May 2012 and October 2014; second, allowing for comparisons with other musical scenes in Portugal and/or with punk scenes in other countries. Here, we must obviously consider the social condition of these protagonists, including not only their class origin and present affiliation but also other relevant
}

characteristics, such as gender and age. Thus, this article will explore the following topics: roles and functions within the punk scene, gender relations, age groups and the process of ageing, territorial placement-both in terms of origin and of residence, educational capital, and socio-occupational group.

Keywords: Portugal / music scenes / punk, social profiles / class / gender / age / educational capital / territorial placement / socio-occupational groups

Résumé : Cet article présente une caractérisation de la scène punk portugaise, entre 1977 et 2014, tout en tenant compte des profils sociaux de ses protagonistes. II est basé sur la proposition sociologique selon laquelle le positionnement social des acteurs sociaux influe sur ce qu'ils font, disent ou sentent. Leur profilage social aidera à comprendre leur rôle dans la scène musicale. Cette approche a été jugée fondamentale dans l'interprétation des cultures jeunes ayant émergé dans le contexte d'après-guerre et la façon dont ils ont repensé la culture pop. Dans cet article, nous avons deux objectifs particuliers : d'une part, établir un portrait des principaux personnages de la scène punk portugaise à travers la définition des profils sociaux de 214 personnes interviewées entre mai 2012 et octobre 2014 ; d'autre part, permettre des comparaisons avec d'autres scènes musicales au Portugal, et/ou avec des scènes punk dans d'autres pays. Ici, nous devons évidemment tenir compte de la condition sociale de ces protagonistes, y compris leur origine de classe et sa présente affiliation, mais aussi d'autres caractéristiques pertinentes, telles que le sexe et l'âge. Ainsi, cet article va explorer les thèmes suivants : les rôles et les fonctions des sujets au sein de la scène punk; les relations entre les sexes ; les différents groupes d'âge et le processus de vieillissement ; les localisations des sujets dans le territoire portugais, à la fois en termes d'origine et de résidence ; le capital scolaire; et les groupes socio-professionnels.

Mots clés : Portugal / scènes musicales / punk / portraits sociaux / classe / sexe / âge / capital scolaire / localisation territorial / groupes socioprofessionnelles 


\section{Introduction:}

\section{Understanding}

\section{Music Scenes Also}

from a Social Space

Perspective

This article will present a characterisation of the Portuguese punk scene between 1977 and 20I4, while considering the social profiles of its protagonists. ${ }^{1}$ It is based on the sociological principle that the social positioning of social actors involved influences what they do, say, and feel. Their social profiling will help understand their role in the musical scene. This approach has been deemed fundamental in interpreting youth cultures emerging post-war and the way in which they re-equated pop culture (Pais, 2003; Pais \& Blass, 2004; Bennett, 2004 \& 2013; Bennett \& Peterson, 2004).

1 The project "Keep it simple, make it fast! Prolegomenons and punk scenes, a road to Portuguese contemporaneity (1977-2012) (PTDC/CSSOC/118830/2010)" is funded by FEDER-through the COMPETE Operational Program from the FCT, the Foundation for Science and Technology. It is led by the Institute of Sociology of The University of Porto (IS-UP) and developed in partnership with the Griffith Centre for Cultural Research (GCCR) and Lleida University (UdL). The following institutions are also participants: Faculty of Economics of University of Porto (FEP), Faculty of Psychology and Educational Sciences of the University of Porto (FPCEUP), Faculty of Economics of the University of Coimbra (FEUC), Centre for Social Studies of the University of Coimbra (CES) and the Lisbon Municipal Libraries (BLX). The project and its results can be found at the site www.
We have two particular aims: first, establishing a portrait of the leading characters in the Portuguese punk scene through the social profiling of $2 \mathrm{I} 4$ individuals interviewed between May 2012 and October 20I4, thus resorting to snowball sampling; second, allowing for comparisons with other musical scenes in Portugal and/or with punk scenes in other countries.

The relationship between young people's social origins and their social experience, as well as the ways in which they establish their identities and lifestyles, have been the focus of Cultural Studies ever since the early days of the Birmingham Centre for Contemporary Cultural Studies. Two main research questions guided their initial works: how far did youth musical cultures express the world of the working class in industrial and tertiary cities in the I950s, I960s, and i970s? And how far can it be said that the songs, artefacts, and collective rituals of such cultures represented resistance to social order (Hall \& Jefferson, 1976)? Post-war sociological studies on western music scenes should, thus, focus also on the sociology of power and class.

It was within this theoretical frame that Dick Hebdige (1979) developed his emblematic work on "subcultures." Hebdige associates punk subculture with a revolt against I970 socio-economic conditions in England, but he also shows the ways in which it culturally interprets and affirms that same revolt through a specific style: "Though punk rituals, accents and objects were deliberately used to signify working-classness, the exact origins of individual punks were disguised or symbolically disfigured by the make-up, masks and aliases which seem to have been 
used, like Breton's art, as ploys 'to escape the principle of identity" (Hebdige, 1997: 140).

Two reductionisms should then be rejected: limiting punk culture to a simple, straightforward expression of a given social condition and reducing the social links of that culture and its protagonists to working class experience. That is, actually, the core of most criticism to Cultural Studies, particularly since the 9os, accusing them of forcing an excessively narrow, class-based homology and overlooking the specific developments of youth cultures outside the Anglo-Saxon context. Sarah Thorton (1996), for example, shifts the focus of the analysis to the constitution of "subcultural capital": subcultures are built by young people transitioning to adult life and negotiating status and power within their "own worlds." They are subcultures in the sense that they are placed in a subordinate or underground (sub-ground) position regarding the dominant culture (Gelder \& Thornton, 1997: 4). But they, themselves, are defined by microstructures of power, and the relevant forms of "subcultural capital" operating in them are neither centred nor determined by class. Quite the contrary: the distinctions in subcultural capital may even obliterate differences in class.

In fact, as underlined by Andy Bennett (2006), one should not ignore that the concept of subculture was introduced and developed in a remarkably ideological context. This explains some essentialist definitions of subcultures and the attributing to them of a level of socio-political "resistance" as a virtually necessary characteristic. It is prudent to start off on the notion that youth (sub)cultures are more diffuse and more transitive and can be integrated or diluted in multiple ways into late capitalism's cultural industry. They are not artefacts brought forth by a single social class (Bennett, 2012) but rather phenomena that, through a variety of mediators, include and process multiple social references and roots (Muggleton, 2000; O'Connor, 2002; Muggleton \& Weinzierl, 2003; Nilan \& Feixa, 2006).

The logical conclusion is that it does make sense to inquire into the actual social positioning of the protagonists of musical scenes, as we will do here for punk, not in order to "explain" the dynamics of each scene merely based on that information but rather to better understand the interaction with certain relevant traits of the societal milieu. In order to do so, we must obviously consider the social condition of these protagonists, including not only their class origin and present affiliation but also other relevant characteristics, such as gender and age. Thus, this article will explore the following topics: roles and functions within the punk scene, gender relations, age groups and the process of ageing, territorial placement-both in terms of origin and of residence, educational capital, and socio-occupational group. Based on this list of indicators, we will be able to show the diversity in the Portuguese punk scene and compare it to others.

\section{Polyvalence}

The information we will work on is the result of semi-structured interviews of 2I 4 individuals considered strongly linked to the Portuguese music scene in a variety of ways. Interviewees were selected based on snowball sampling, first, starting with 
a core group established by the researchers and then following their own networks to a level of saturation (i.e., contacts became repeated and no relevant innovation was provided).

The first aspect to consider is the mode of participation in the punk scene. We outlined three main categories: the practising of music, mediating activities (fanzine and/ or phonographic edition, promotion of concerts, commerce of records, reviewing, radio hosting and so on), and intense and passionate consumption (in the usual terms, being a fan). More than two-thirds of the interviewees are musicians: $45 \%$ active musicians and $24 \%$ retired musicians. Nearly half of all interviewees have some experience as mediators: $34 \%$ are active mediators and I3 \% currently inactive. Finally, $24 \%$, i.e., one in four, define themselves as fans. The combination of multiple roles is the norm for two-fifths, especially when it comes to combinations of active musicians and mediators (20\%) and fans and inactive musicians (Iо\%) (Table I).

This plurality of roles and the circulation implied are clearly associated with the dynamics of music scenes, but especially to punk scenes, which share a particular DIY-“do it yourself" philosophy (Rosen, 1997; Bennett, 2013; Gomes, 2013). It is also a logical constraint, resulting from the small size and marginal nature of this music scene, which then requires taking on multiple roles, either over the course of a lifetime or even simultaneously (see Box I ${ }^{2}$ ). This ethos of self-production and polyvalence is a practical necessity that was

\begin{tabular}{|l|l|c|}
\hline Profiles of the interviewees & No. & $\mathbf{\%}$ \\
\hline Active Musician & 48 & 22.4 \\
\hline Active Musician and Mediator & 42 & 19.6 \\
\hline Fan & 29 & 13.5 \\
\hline Active Mediator & 27 & 12.6 \\
\hline Inactive Musician and Fan & 22 & 10.2 \\
\hline Inactive Musician & 14 & 6.5 \\
\hline Inactive Musician and Mediator & 11 & 5.1 \\
\hline Inactive Mcdiator & 10 & 4.6 \\
\hline Active Musician and Inactive Mediator & 7 & 3.2 \\
\hline Inactive Musician and Active mediator & 4 & 1.8 \\
\hline Total & $\mathbf{2 1 4}$ & $\mathbf{1 0 0}$ \\
\hline
\end{tabular}

Table 1: Profiles of the interviewees

also observed elsewhere (see Pilkington, 2014 for Russian punk, and Greene, 2012 for Peruvian punk).

\section{Male Domination}

The second element that stands out as we socially profile participants in the Portuguese punk scene is gender. As is the general case when it comes to rock, this music scene is mostly male. The few women present take on secondary roles. Figures are impressive: out of 2I 4 interviewees, only I $4 \%$ were female.

Some scholars have attempted to "cleanse" this negative image of modern youth pop culture. For example, Angela McRobbie and Jenny Garber $(1993,1997)$ recall that the increased earnings that were left available for consumption during the post-war period were unevenly distributed, leaving women at a clear disadvantage. On the other hand, patterns of consumption 


\section{Box 1: Igor's multiple activities}

Igor is 34 years old and lives in Lisbon. He finished high school and has since been investing heavily in his professional development. He is now a practitioner of Naturopathy. He has had a strong connection to the punk scene ever since he was 15 years old, as made evident by the 10 music bands in which he takes or has taken the roles of lead singer and/or drummer. He took part in residential squats in Germany and Spain (Barcelona). He clearly demonstrates full involvement in the punk lifestyle, including the bands, the communitarian experience, managing of fanzines, selling of phonograms, ownership of distributors, and organising of concerts. $\mathrm{He}$ is also strongly attached to punk, as confirmed by his presently collecting punk items and memorabilia. At 19 he started working at a vegetarian food store where he started learning Chinese medical practices. Then, he moved on to a bio-farming cooperative. Simultaneously, he started a punk music distributor. He worked for a record store, of which he later became partner. Later, he returned to catering and became a kitchen aide in a vegetarian restaurant, which he then explored in the evening for macrobiotic cooking dinners. He also carried on with selling records and with naturopathic consultation and therapeutic cooking classes from home. In 2004, he started teaching kung fu. Currently, he and his wife own a business dealing with macrobiotics and alternative medicine. were structurally different: girls were led to focus on domesticity and family life. It is well known how excluded women were from the public sphere and the "going-out" culture. But the fact that they were more restricted to a domestic form of consumption did not mean that they were left outside cultural change. In fact, the problem may lie, rather, in Cultural Studies not valuing correctly the emergence of ways of socialising and acculturation, which were alternative to the male urban scene and more prevalent indoors, particularly within bedroom doors.

Still, it is also true that gender inequality has remained present over the decades. It can thus be qualified as structural. The clear minority of girls in the punk music scene follows the general trend in consecutive rock and punk subcultures, within and outside the Anglo-Saxon world (Hebdige, 1979; Laing, 1985; Clarke et al., 1997; Fouce, 2006; Downes, 2007; Guerra, 2010 \& 2015; Humeau, 2011; Griffin, 2012; Reddington, 2012; Gololobov et al., 2014; Martin-Iverson, 2014; Crossley, 2015).

The girls that we interviewed not only were a minority but also took on secondary and backstage roles within the punk scene. If they did play a leading role, it was mostly that of lead singer (as in the case of II out of our 30 female interviewees). Box 2 describes the trajectory of one of the best-known girls, eliciting the way in which her successive collaborations were seen, both by her and her peers, as "having fun/playing around" and "experimenting," rather than a serious investment. 


\section{Box 2: The trajectory of Alda, the punk girl}

Alda is now 44 years old and lives in a traditional quarter of Lisbon. She completed the high school level in an arts school. Currently she is a self-employed jewellery maker. Her involvement with the punk scene started off early, by going to concerts and hanging around activists. She was the girlfriend of one of the members of the punk band N.A.M. (Núcleo de Atrasados Mentais"Mental Retard Section"). During her high school years (in the mid-eighties), Alda had an all-girl band called K Motim ("What a Riot"), but they only performed once in school. The band was created for fun, as a possibility for experimentation and self-expression, rather than as something to be taken seriously.
Later, Alda rehearsed a few times with Censurados ("Censored"). At the time, band leader João Ribas wanted "a girl singing" and invited her. She even sang live at Oceano Bar, but it was a short-lived experience, because, as she herself confesses, not knowing how to sing, Alda would simply shout, and she would lose her voice at every rehearsal. She also spent time living in a squat in Germany. In other words, one of the women most commonly referred to by members of the punk scene is this prevalent in their memory, not because of the relevance of her roles but rather for the consistency of her presence and the depth of her personal connexions.
Looking at Table 2, which compares roles in the scene by gender, it is apparent that $43 \%$ of women declare themselves as just fans (opposite of $9 \%$ of men); $40 \%$ had or have some activity in musical performance (against $74 \%$ of the men); only $23 \%$ claim to still have that activity (against $49 \%$ of the men); and only I $7 \%$ claim to take on mediator roles (opposite of $37 \%$ of the men).

Gender inequality and a strong male hegemony are defining traits of both Portuguese and international music scenes, in a rather conventional way: both in the stereotypical representation of gender in lyrics (Silva \& Guerra, 2015: 198-210) and in the division of stage and backstage roles, with its justification being attributed to required resilience and physical strength (Reddington,
2012). Punk tends to reproduce the social dichotomy of a public (hence, "male") sphere, and a private (hence, "female") sphere. Stage, front-row assistance, and production are male territory, and backstage, wings, the back of concert rooms, supporting roles in catering, costumes, selling of merchandise, records, fanzines, videos, and photos are all female territory (O'Hara, 1999).

\section{Youth and Ageing}

If we now turn our attention to the age distribution of our 2I4 interviewees, the young-adult demographic stands out. The average age is 40 years old. Of the interviewees, $31 \%$ were over 45 years old at the time 


\begin{tabular}{|c|c|c|c|c|c|c|}
\hline \multirow[b]{3}{*}{ Profiles of the interviewees } & \multicolumn{4}{|c|}{ Gender } & \multirow{2}{*}{\multicolumn{2}{|c|}{ Total }} \\
\hline & \multicolumn{2}{|c|}{ Female } & \multicolumn{2}{|c|}{ Male } & & \\
\hline & No. & $\%$ & No. & $\%$ & No. & $\%$ \\
\hline Active Musician & 5 & 16.7 & 43 & 23.4 & 48 & 22.4 \\
\hline Inactive Musician & 4 & 13.3 & 10 & 5.4 & 14 & 6.5 \\
\hline Active Mediator & 3 & 10.0 & 24 & 13.0 & 27 & 12,6 \\
\hline Inactive Mediator & 2 & 6.7 & 8 & 4.4 & 10 & 4.7 \\
\hline Fans & 13 & 43.3 & 16 & 8.7 & 29 & 13.6 \\
\hline Active Musician and Mediator & 2 & 6.7 & 40 & 21.7 & 42 & 19.6 \\
\hline $\begin{array}{l}\text { Active Musician and Inactive } \\
\text { Mediator }\end{array}$ & 0 & 0.0 & 7 & 3.8 & 7 & 3.3 \\
\hline $\begin{array}{l}\text { Inactive Musician and Active } \\
\text { Mediator }\end{array}$ & 0 & 0.0 & 4 & 2.2 & 4 & 1.9 \\
\hline Inactive Musician and Mediator & 1 & 3.3 & 10 & 5.4 & 11 & 5.1 \\
\hline Inactive Musician and Fan & 0 & 0.0 & 22 & 12.0 & 22 & 10.3 \\
\hline Total & 30 & 100 & 184 & 100 & 214 & 100 \\
\hline
\end{tabular}

Table 2: Profiles of the interviewees by gender

of the interview, and only i8\% (less than two-fifths) were under 30 . This distribution is connected to the object and method of our research, focused on the emergence and development of the punk scene in Portugal between 1977 and 20I4. In fact, our oldest interviewees are the protagonists of the first waves of punk affirmation, and they naturally take on a more central role in an investigation that seeks to recapture those waves (see also Humeau, 2011, for France). Still, it is worth noting that $26 \%$ of those above 45 years of age still practise punk music, $21 \%$ still act as mediators (concert organisers, fanzine or record producers, and so on), and $34 \%$ see themselves as fans (Table 3). These numbers confirm the criticism, directed at the first studies of the Birmingham School, that underground cultures cannot be reduced to youth cultures (Hebdige, 1979; Clarke et al., 1997).

On the other hand, the sheer size of the

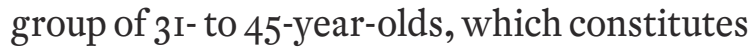
roughly half of our total of interviewees, suggests continuity and generational renewal in punk, in opposition to its depiction as a fleeting movement in the 70 s/80s. In fact, almost one in every two members of that young-adult demographic ( $47 \%$ ) claim to practise (or "continue to practise") music, and $42 \%$ take on mediator roles. The generation renewal extends widely: $5 \%$ of our interviewees range between 15 and 20 years 


\begin{tabular}{|c|c|c|c|c|c|c|c|c|}
\hline \multirow{3}{*}{ Profiles of the interviewees } & \multicolumn{6}{|l|}{ Age } & \multirow{2}{*}{\multicolumn{2}{|c|}{ Total }} \\
\hline & \multicolumn{2}{|c|}{$\begin{array}{l}\text { 15-30 years } \\
\text { old }\end{array}$} & \multicolumn{2}{|c|}{$\begin{array}{l}31-45 \text { years } \\
\text { old }\end{array}$} & \multicolumn{2}{|c|}{$\begin{array}{l}>45 \text { years } \\
\text { old }\end{array}$} & & \\
\hline & No. & $\%$ & No. & $\%$ & No. & $\%$ & $\mathrm{~N}$ & $\%$ \\
\hline Active Musician & 19 & 50.0 & 19 & 17.4 & 10 & 14.9 & 48 & 22.4 \\
\hline Inactive Musician & 1 & 2.6 & 5 & 4.6 & 8 & 11.9 & 14 & 6.5 \\
\hline Active Mediator & 3 & 7.9 & 16 & 14.7 & 8 & 11.9 & 27 & 12.6 \\
\hline Inactive Mediator & 0 & 0.0 & 5 & 4.6 & 5 & 7.5 & 10 & 4.7 \\
\hline Fan & 2 & 5.3 & 11 & 10.1 & 16 & 23.9 & 29 & 13.6 \\
\hline Active Musician and mediator & 10 & 26.3 & 27 & 24.8 & 5 & 7.5 & 42 & 19.6 \\
\hline $\begin{array}{l}\text { Active Musician and Inactive } \\
\text { Mediator }\end{array}$ & 0 & 0.0 & 5 & 4.6 & 2 & 3.0 & 7 & 3.3 \\
\hline $\begin{array}{l}\text { Inactive Musician and Active } \\
\text { Mediator }\end{array}$ & 0 & 0.0 & 3 & 2.8 & 1 & 1.5 & 4 & 1.7 \\
\hline Inactive Musician and Mediator & 1 & 2.6 & 5 & 4.6 & 5 & 7.5 & 11 & 5.4 \\
\hline Inactive Musician and Fan & 2 & 5.3 & 13 & 11.9 & 7 & 10.5 & 22 & 10.8 \\
\hline Total & 38 & 100 & 109 & 100 & 67 & 100 & 214 & 100 \\
\hline
\end{tabular}

Table 3: Profiles of the interviewees by age

old, $4 \%$ of them are between $2 \mathrm{I}$ and 25 years old, and $9 \%$ are between 26 and 30 years old. The punk scene is, thus, far from being a topic for History.

The nature of their involvement in the punk scene varies significantly, according to age. As we have seen, among the youngest interviewees, we find most of the active musicians $(76 \%)$ and the least mediator-alone roles $(8 \%)$ or simple fans $(5 \%)$. On the contrary, the least number of active musicians (26\%) and greatest number of fans-only (24\%) is to be found among the older interviewees. It is worth noticing that the number of "former musicians, now fans" is more significant at later stages (I2\% for $3 \mathrm{I}^{-}$to 45 -year olds; II $\%$ for evidence of the importance and effect of ageing in the punk subculture and demonstrate how important the ageing process is for the dynamics of the scene. They confirm Andy Bennett's (2013) enlarging of Frith's (1978) expression. If, as put by Frith, "the sociology of rock is inseparable from the sociology of youth," it is also inseparable from the ageing of young generations. Boxes 3 and 4 clearly illustrate the age-related diversity of roles by describing the experience of age-diverse protagonists.

The Portuguese punk scene is thus characterised both by polyvalence (multiple functions played out simultaneously by individuals who are at the same time musicians and each other's producers and 
consumers) and a strong effect of a given life trajectory (a more performative role at a younger age, followed by more mediator-like and symbolic consumer attachment at later stages). As shown by Bennett (2006, 2013) and Hodkinson (2002), age is a crucial element in understanding the variation over time in members' connexion to subcultures

\section{Box 3: Dinis and youth pluriactivity in the current punk scene}

Dinis is 27 years old and lives in Seixal. He finished high school and entered a family business connected to video and photography. He got involved with punk when he was quite young, as a result of skating and a desire for fast-beat music. Today he is quite active: in parallel with the family business, he is a member of several bands-Skrotes, Broken Toillet, Tiro no Escuro ("Shot in the Dark"), Kids Decay, A Bit of Braindead, Arson, and Stevenseagal-and since 2009, he has also been in charge of the label Destroy It Yourself and the fanzine Zine Reset Everything. Bands, record house, distributor, and promotor can all be associated to the "do it yourself" ethos, as a direct link to the need felt by Dinis's bands to ensure their own records and concerts, free from the bureaucratic restraints of Portuguese mainstream music industry.

\section{Box 4: Ivo's trajectory: from founding musician to punk lover}

Ivo is currently 56 years old and lives in Lisbon. He did not study beyond completing primary school. He started working very young in order to help his family and has held multiple jobs. He is now working as an operational assistant in a transport company. He was part of a band-Aqui d'el Rock, which is considered one of the precursors of punk in Portugal, but today he sees himself as merely a fan. After the band split up and Ivo realised he would not be able to make a living out of music, he abandoned the scene for over 20 years. Only recently did he take part in other musical (non-punk related) projects that, nevertheless, failed, as family life and work were not compatible with rehearsals and performances. Ivo keeps every news item and register of events connected to Aqui d'el-Rock, Lisbon's Bairro do Relógio (the band's original location), and the Portuguese punk scene in a remarkable and unusual effort to archive. 
like punk: it gradually transforms into a more affectionate and symbolic attachment, and performative roles tend to fade out, unless they become professional. The ways in which to connect to cultural and musical worlds are multiple and cannot be circumscribed to a single model of music lovers (Hennion, 2001; Howes, 2012; Guerra \& Bennett, 2015).

\section{An Urban and Suburban Scene}

In addition to being an eminently male world and to its continued appeal to and involvement by participants from diverse age groups, the territorial representation of Portuguese punk defines it clearly as urban and suburban. These urban roots are present in several other music scenes (cf. Crossley, 2015). In our case, the large majority of protagonists interviewed are concentrated in the urban areas of Lisbon and Porto, both in terms of birthplace (Map 1) and current place of residence (Map 2). Of the interviewees, $5 \mathrm{I} \%$ were born in or around the capital city of Lisbon, and $49 \%$ lived there at the time of the interviews; $12 \%$ were born in or around Porto, and $\mathrm{I} 8 \%$ resided there when interviewed.

The urban setting of punk is not surprising. In big cities it is easier to find a greater diversity in ways of life and a wider production and circulation of different forms of cultural expression (cf. Costa, 2007). When it comes to music, the works penned by Paula Guerra (2010)-on alternative rock, José Alberto Simões (2011)-on hip-hop music, and music, among others, describe the way in which Portugal's two main urban areas have been the favoured locations for the incubation and development of new art grammars and new models of production and dissemination.

An international comparison backs this notion: in Spain, punk came at the time of the democratisation, following Franco's regime, and of the emergence of Madrid's movida (Fouce, 2004 \& 2006); in France it was brought to being by young people coming mostly from Lyon and Paris (Verger, 1991; Sapiro, 1999; Humeau, 2011); in what is today Russia, the dissemination of punk began in Moscow and Saint Petersburg (Pilkington, 2014). Punk is indeed urban and suburban. It can be found in territories characterised by diversity and population density and by strong interconnectedness. It can be traced in late modernity and cosmopolitanism.

These truths, however, should not be cause to forget another relevant aspect in the development of the Portuguese punk scene: territorial dissemination. The sharing of multiple traits of youth social condition, the current speed and spread of information, and the nature of production (the DIY process) are partly the reasons for said dissemination. Our sample bears clear evidence of this when it shows that it is in Lisbon and its whereabouts that the number of over 45-year-olds is more significant (Map 3). Also, the formation (and performing) of self-claimed punk bands virtually everywhere in the country is relevant (an analysis of this can be found in Silva \& Guerra, 2015: 62-67). The more recent emergence of multiple local youth and music scenes away from the areas of Lisbon and Porto is clearly influenced by the DIY philosophy. This is a key strategy 


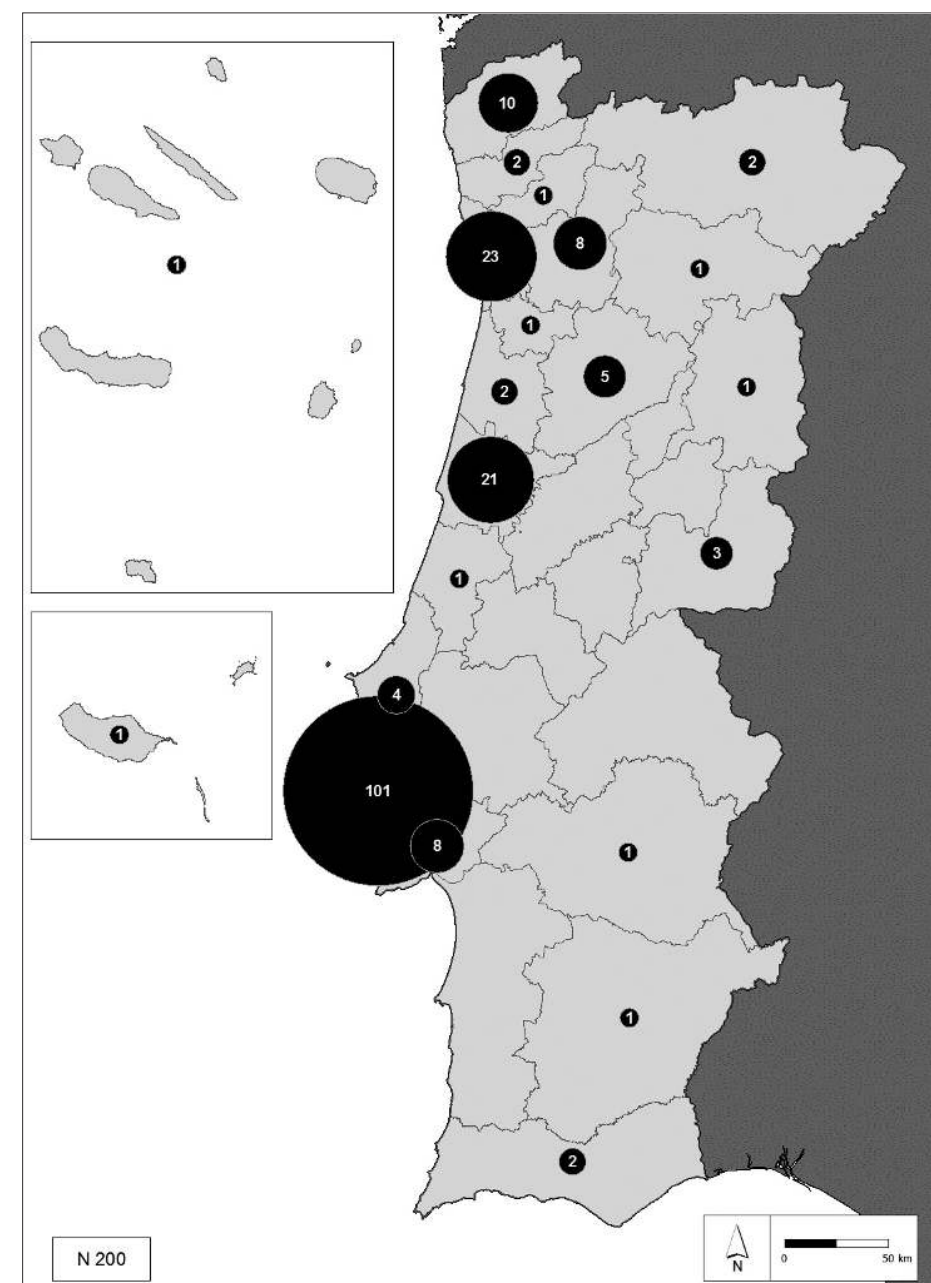

Map 1: number of interviewees by place of birth

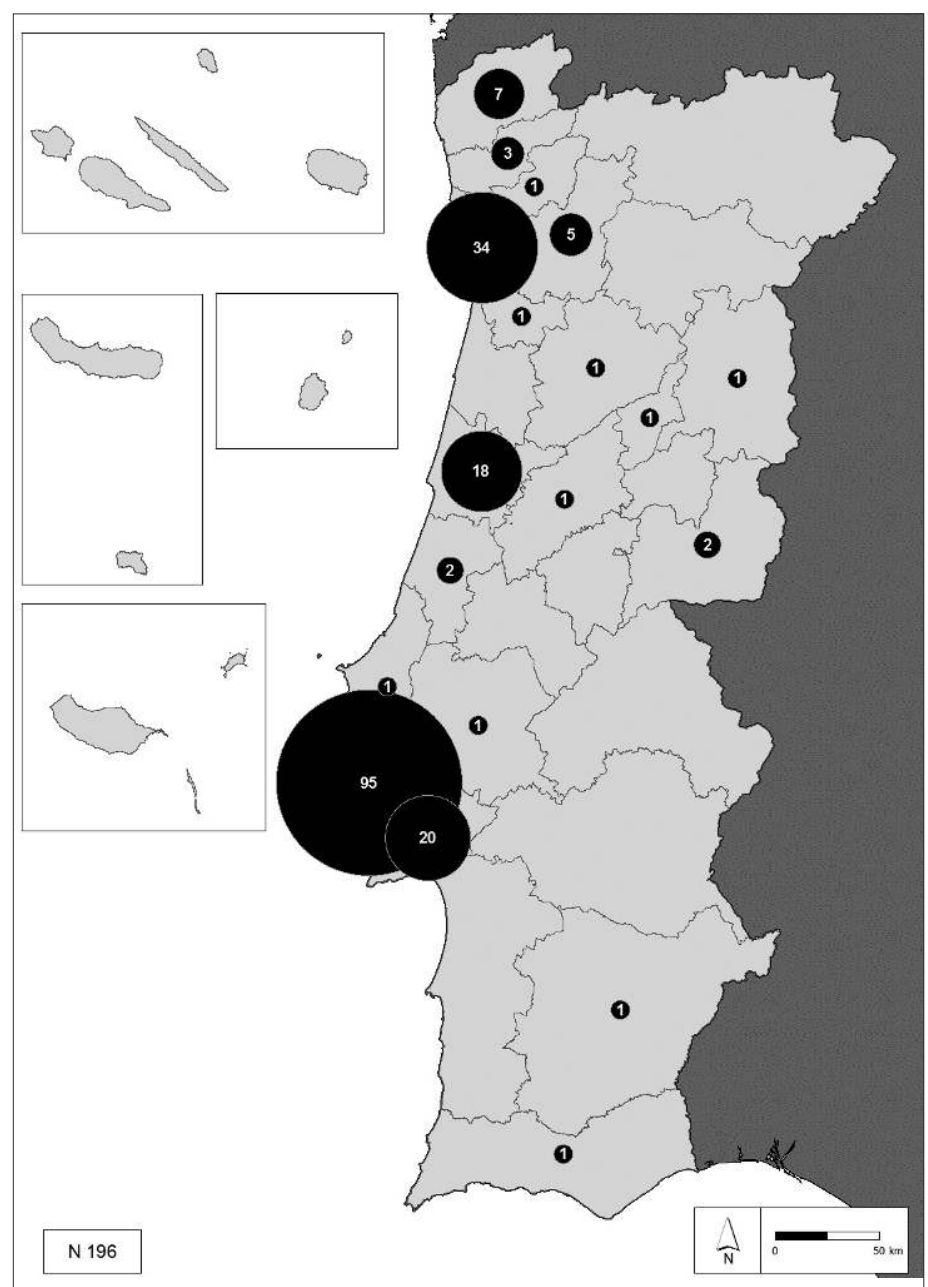

Map 2: number of interviewees by place of residence 


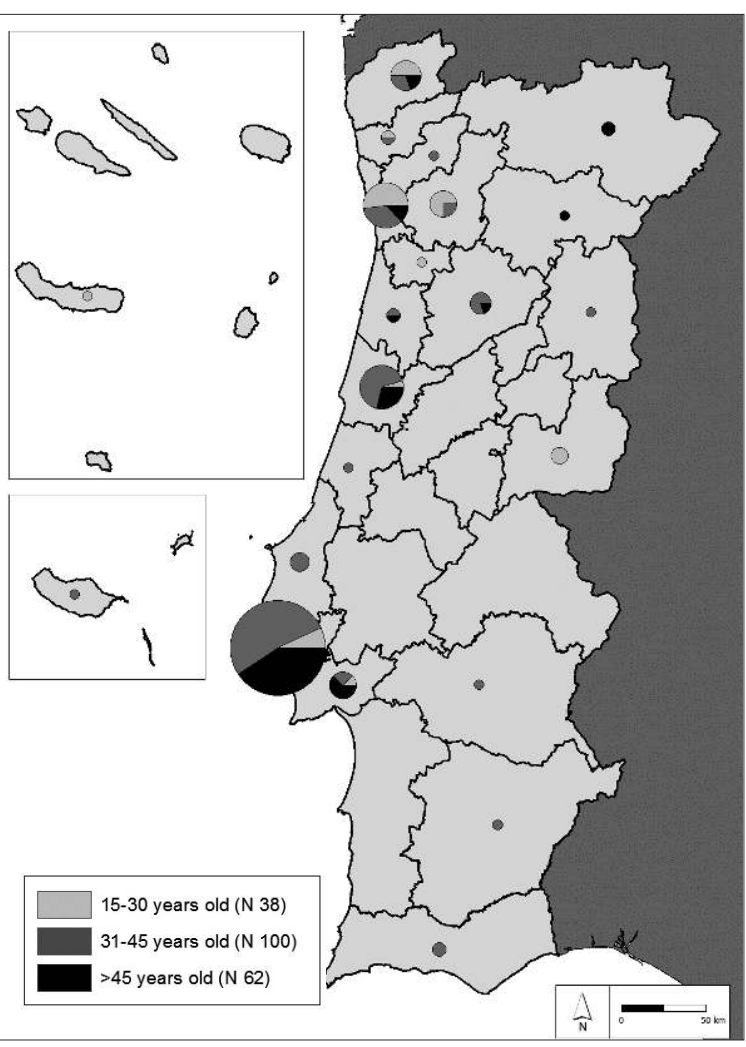

Map 3: number of interviewees by place of birth and age

in getting through to more isolated musical and cultural contexts, with fewer resources overall (musical resources, venues, equipment, and even participants) (Moreira, 2013). Box 5 is a clear example.

\section{Is Punk a Popular Subculture?}

Several authors have claimed that the protagonists of the punk movement come mostly from the working classes (Hebdige, 1979; Humeau, 2011; Gololobov,
Portugal, judging by the origins and social position of our interviewees. Portuguese punk seems to be rooted in urban, educated middle classes. Similar to Spain-where young people from relatively well-off backgrounds had the resources to travel and buy records and accessories and brought punk from London to Madrid (Fouce, 2006), in Portugal, the first wave, in the late 7os, was dominated by young people of relative social, economic, and educational capital. This profile will last over time.

The group interviewed is quite highly educated, particularly when compared to the average Portuguese population. Of those interviewed, $38 \%$ hold a complete Higher Education degree, $\mathrm{I} 3 \%$ have attended some form of Higher Education, but not (or not yet) completed it, and 33\% finished high school, which leaves very few at an elementary level of education. This advantage was already there in most families of origin: $33 \%$ of fathers and $30 \%$ of mothers attended some kind of institution of Higher Education (which is approximately twice as much as the Census 201 I's $15 \%$ for the national population); $59 \%$ of fathers and $54 \%$ of mothers held either a high school diploma or a degree (Table 4).

But notice what happens when you cross the schooling of each interviewee with that of his/her own parents (Table 5). ${ }^{3}$ Two other tendencies can be seen, apart from the intergenerational replication of educational capital.

3 We will naturally leave out the situations with a residual number of cases in order to focus on those sufficiently relevant from which to draw conclusions. 


\section{Box 5: Adriano and living punk away from the big centres}

Adriano is 26 years old and lives in Castelo Branco. He holds a master's degree and, at the time of the interview, was a trainee at the Municipality of Castelo Branco. His involvement with punk began at the age of 15 , when he started attending concerts. Shortly after he created his own band Hepatite $P$ ("Hepatitis P"), under the influence of other Portuguese bands like Mata-Ratos ("RatKillers"). Everything was done according to "do it yourself" to the extent that Adriano had never before played the bass. The same logic lay behind the organising of concerts and festivals-like Bastard Rock-and is responsible for the establishment of a cultural association Cachos de Sucesso ("Bunches of Success"), focused on ensuring a concert venue in Castelo Branco. One can say that DIY directs the entire punk scene in Adriano's city.

\begin{tabular}{|l|l|l|l|l|l|l|}
\hline \multirow{2}{*}{ Level of Education Attainment } & \multicolumn{2}{|l|}{ Interviewee } & \multicolumn{2}{l|}{ Father } & \multicolumn{2}{l|}{ Mother } \\
\cline { 2 - 8 } & No. & $\mathbf{\%}$ & No. & $\mathbf{\%}$ & No. & \% \\
\hline Incomplete Elementary Education & 5 & 2.3 & 60 & 28.0 & 67 & 31.3 \\
\hline Complete Elementary Education & 13 & 6.1 & 23 & 10.8 & 28 & 13.1 \\
\hline Incomplete Secondary School & 16 & 7.5 & 4 & 1.9 & 2 & 0.9 \\
\hline Complete Secondary School & 70 & 32.7 & 52 & 24.3 & 48 & 22.4 \\
\hline Incomplete Higher Education & 28 & 13.1 & 5 & 2.3 & 5 & 2.3 \\
\hline Higher Degree & 82 & 38.3 & 65 & 30.4 & 60 & 28.0 \\
\hline Does not know/Will not answer & 0 & 0.0 & 5 & 2.3 & 4 & 1.9 \\
\hline Total & $\mathbf{2 1 4}$ & $\mathbf{1 0 0}$ & $\mathbf{2 1 4}$ & $\mathbf{1 0 0}$ & $\mathbf{2 1 4}$ & $\mathbf{1 0 0}$ \\
\hline
\end{tabular}

Table 4: Levels of educational attainment (interviewees and parents) 


\begin{tabular}{|c|c|c|c|c|c|c|}
\hline \multirow[b]{2}{*}{$\begin{array}{l}\text { Father's } \\
\text { Level of } \\
\text { Education } \\
\text { Attainment }\end{array}$} & \multirow[b]{2}{*}{$\begin{array}{l}\text { Mother's Level } \\
\text { of Education } \\
\text { Attainment }\end{array}$} & \multicolumn{3}{|c|}{ Interviewee's Level of Education Attainment } & \multirow[b]{2}{*}{$\begin{array}{l}\text { Total } \\
(\%)\end{array}$} & \multirow[b]{2}{*}{$\begin{array}{l}\text { Total } \\
\text { (Number } \\
\text { of cases) }\end{array}$} \\
\hline & & $\begin{array}{l}\text { Elementary } \\
\text { Education } \\
\text { (complete or } \\
\text { not) }\end{array}$ & \begin{tabular}{|l} 
Secondary \\
Education \\
(complete or \\
not)
\end{tabular} & $\begin{array}{l}\text { Higher } \\
\text { Education } \\
\text { (complete or } \\
\text { not) }\end{array}$ & & \\
\hline \multirow{3}{*}{$\begin{array}{l}\text { Elementary } \\
\text { Education } \\
\text { (complete or } \\
\text { not) }\end{array}$} & $\begin{array}{l}\text { Elementary } \\
\text { Education }\end{array}$ & 12.3 & 48.0 & 39.7 & 100 & $(73)$ \\
\hline & $\begin{array}{l}\text { Secondary } \\
\text { Education }\end{array}$ & 14.3 & 42.9 & 42.9 & 100 & (7) \\
\hline & Higher Education & 33.3 & 33.3 & 33.3 & 100 & (3) \\
\hline \multirow{3}{*}{$\begin{array}{l}\text { Secondary } \\
\text { Education } \\
\text { (complete or } \\
\text { not) }\end{array}$} & $\begin{array}{l}\text { Elementary } \\
\text { Education }\end{array}$ & 11.8 & 41.2 & 47.1 & 100 & $(17)$ \\
\hline & $\begin{array}{l}\text { Secondary } \\
\text { Education }\end{array}$ & 8.3 & 25.0 & 66.7 & 100 & $(24)$ \\
\hline & Higher Education & 6.7 & 26.7 & 66.7 & 100 & $(15)$ \\
\hline \multirow{4}{*}{$\begin{array}{l}\text { Higher } \\
\text { Education } \\
\text { (complete or } \\
\text { not) }\end{array}$} & $\begin{array}{l}\text { Elementary } \\
\text { Education }\end{array}$ & 0.0 & 25.0 & 75.0 & 100 & $(4)$ \\
\hline & $\begin{array}{l}\text { Secondary } \\
\text { Education }\end{array}$ & 0.0 & 38.9 & 61.1 & 100 & $(18)$ \\
\hline & Higher Education & 2.1 & 38.3 & 59.6 & 100 & (47) \\
\hline & $\begin{array}{l}\text { Does not } \\
\text { know/will not } \\
\text { answer }\end{array}$ & 0.0 & 100.0 & 0.0 & 100 & (1) \\
\hline \multirow{3}{*}{$\begin{array}{l}\text { Does not } \\
\text { know/will not } \\
\text { answer }\end{array}$} & $\begin{array}{l}\text { Elementary } \\
\text { Education }\end{array}$ & 0.0 & 100.0 & 0.0 & 100 & (1) \\
\hline & $\begin{array}{l}\text { Secondary } \\
\text { Education }\end{array}$ & 0.0 & 100.0 & 0.0 & 100 & $(1)$ \\
\hline & $\begin{array}{l}\text { Does not } \\
\text { know/will not } \\
\text { answer }\end{array}$ & 33.3 & 33.3 & 33.3 & 100 & (3) \\
\hline Total & & 8.4 & 40.2 & 51.4 & 100 & $(214)$ \\
\hline
\end{tabular}

Table 5: Level of interviewees' educational attainment, according to respective parents' level of educational attainment (row percentage) 


\section{Box 6: Margarida and Luísa's interrupted education}

Margarida is 40 years old. She comes from Lisbon but lives in Switzerland, where she works as an employed beautician. Both parents hold degrees and are journalists, but Margarida did not study beyond the 6th grade. According to her, she only cared about having fun and found school too strong of a constraint on her freedom for personal, ethical, and aesthetic expression. The "streets"-and bars like Rock Rendez Vous and Oceano-were far more appealing. Eventually, she had a child at 16 and dropped out of school altogether, abandoning also a perceived smothering by her parents.
Luisa is 40 years old and lives in Lisbon. She stopped studying after high school, because she always felt that school was too formal and unappealing. She has taken on a myriad of occupations, all temporary and more or less precarious. At the time of the interview, she was unemployed, and her last paid job had been conducting survey interviews. Both her parents are Full Professors, the highest position possible at the university level. She spent a long time living in Paris but remained uninterested in any kind of formal education.
The first of those two tendencies was to be expected, given the recent trend in Portuguese society towards greater schooling: the vast majority of interviewees coming from families with low levels of education achieved a significantly higher level of education attainment. For example, $88 \%$ of protagonists whose parents both possess less than a high school degree obtained a high school diploma, and $40 \%$ of them reached Higher Education. Also, two-thirds of protagonists whose parents both hold high school diplomas reached Higher Education. Portugal does not seem to share the blocking in social mobility that Humeau (2011) signalled in the French punk and hardcore scene.

The second tendency shown is more peculiar and in a reverse direction: $40 \%$ of interviewees whose parents both held Higher
Education degrees (and 39\% of those with just one parent holding a degree) actually failed to obtain one themselves. Age restrictions (interviewees under 18 years old at the time of the interview) only account for a total of five cases (2\%). Box 6 clearly illustrates these interrupted paths and consequent downgrading.

We have paid particular attention to these data, because they suggest a very significant fact: there is diversity in conditions, or profiles, to be found in the Portuguese punk scene. Can it be said that an analysis of social class and profession corroborates this perceived diversity?

Once we look at the occupations of our interviewees, there is a natural majority of professions linked to music, art, communication, and teaching. At the time of the interview, $82 \%$ of our chosen protagonists 
were working, II \% were unemployed, and $6 \%$ were still studying (in addition, there were also two working students and an interviewee already retired). If one uses, to establish the occupations of the working interviewees, unemployed or retired, the Portuguese Classification of Occupations (INE 2OII), to the double digit, the most represented occupations are, in descending order, the following: "Specialists in Judicial, Social, Artistic, and Cultural Matters" (22\% of the total), "Teachers" (8\%), "Specialists in Physical Sciences, Mathematics, Engineering, and Related Techniques" ( $7 \%$ ) and "Middle-Level Technicians in Judicial, Social, Cultural, and Similar Services" (6\%). If we continue on to the four digits, the group of "Composers, Musicians, and Singers" (9\%) leads, followed by "Graphic and Communication and Multimedia Designers," "Visual Artists," and "Teachers in Elementary and Secondary Education" (each at 4\%).

The same logic applies when one moves from individual occupational distribution to the distribution by groups of interrelated occupations, that is, by socio-occupational groups. Both distributions are clear indicators of the prevalence of economic elites and new middle classes with a high level of education. Put together, intellectuals and middle managers (groups $4^{+} 5$ in Table 6 ) account for $37 \%$ of interviewees and $4 \mathrm{I} \%$ of their respective families of origin. Entrepreneurs, senior managers, and liberal professionals (groups $\mathrm{I}+2+3$ in Table 6) amount to $35 \%$ of interviewees and $25 \%$ of their families. The prevalence was thus something that was already there in the protagonists' social background. In reverse, only a third of interviewees came in Table 6), including self-employed workers, sales and services personnel, small agricultural owners, and industrial workers. When it comes to the interviewee's own socio-professional status, the proportion diminishes even further, to about a quarter.

In order to deepen our analysis, we crossed the class category of interviewees' families to their own (Table 7), which gave us a more complex understanding of this heterogeneous reality in which ascending and descending social trajectories coexist.

Among the descending movements, the cases of children of businessmen, proprietors, senior managers, and liberal professionals stand out. In fact, out of 53 interviewees that fit this group, 27 (i.e., 51\%) currently occupy lower places in social hierarchy. Still, the probability of "plummeting" to the bottom of the social pyramid (i.e., independent workers, sales and services personnel, rural and industrial labourers) is quite low: I 4 cases (26\%). The ratio diminishes further if the starting point is a family of professional middle class (intellectual and scientific specialists and middle-level technicians and other professionals): I8 cases out of 87 (2I\%). However, the sum of both figures ( 32 out of 212) indicates that descending mobility leading to the bottom of the social pyramid is far from irrelevant. Box 7 illustrates the reasons for and the meaning of such a trajectory.

As for ascending trajectories, they must also be divided in terms of extension. The lines between the proprietary and managing elites and liberal professionals, on the one hand, and educated professionals (senior or middle-level managers), on the other, are not watertight. It is no wonder, then, that out of 87 interviewees coming from families 


\begin{tabular}{|l|l|l|l|l|l|}
\hline \multirow{2}{*}{ Class Category } & \multicolumn{3}{l|}{$\begin{array}{l}\text { Family of } \\
\text { Origin }\end{array}$} & \multicolumn{2}{l|}{ Interviewee } \\
\cline { 2 - 6 } & No. & $\mathbf{\%}$ & No. & $\mathbf{\%}$ \\
\hline 1. Entrepreneurs and Owners (EO) & 8 & 3.7 & 4 & 1.9 \\
\hline 2. Senior Managers (SM) & 34 & 15.9 & 23 & 10.8 \\
\hline 3. Liberal Professionals (LP) & 11 & 5.1 & 48 & 22.4 \\
\hline 4. Intellectual and Scientific Specialists (ISS) & 67 & 31.3 & 52 & 24.3 \\
\hline 5. Middle-Level Technicians and Other Professionals (MLTOP) & 20 & 9.4 & 28 & 13.1 \\
\hline 6. Self-Employed Workers (SEW) & 21 & 9.8 & 16 & 7.5 \\
\hline 7. Sales and Services Personnel (SSP) & 34 & 15.9 & 34 & 15.9 \\
\hline 8. Small Agricultural Owners (SAO) & 1 & 0.5 & 0 & 0.0 \\
\hline 9. Industrial Workers (IW) & 16 & 7.5 & 9 & 4.2 \\
\hline No data available & 2 & 0.9 & 0 & 0.0 \\
\hline Total & $\mathbf{2 1 4}$ & $\mathbf{1 0 0}$ & $\mathbf{2 1 4}$ & $\mathbf{1 0 0}$ \\
\hline
\end{tabular}

Table 6: Class categories of interviewees and of families of origin 4

in the second group, 23 (26\%) moved on to the first group. Much more difficult, and thus significant, is the successful crossing of the threshold beyond either a subordinate employee occupation or a non-liberal, self-employed occupation. In our case, 45 out of 72 interviewees succeeded in doing so and are now senior or middle-level managers, liberal professionals, and proprietors.
That is a total of $63 \%$ (nearly two-thirds), and their trajectory goes hand in hand with and is explained by the more general movement of translation in Portuguese society, with the recent reinforcement of employed middle classes. The case summarised in Box 8 is a clear example of the material and symbolic relevance of such a path, in contrast to Box 7 .
4 In creating the social classes, we followed and adapted the ACM matrix (Almeida, Costa \& Machado, 1988, 1990) under the guise of three principles: first, we confronted interviewees' professions with the $\mathbf{2 0 1 0}$ version of Portuguese Classification of Occupations (Instituto Nacional de Estatística, 2011); second, we considered the fine-tuning put forward by Pereira, Pinto and Queirós (2010) and by Pereira and Queirós (2012), in what concerns the situations of individual pluriactivity, which are relatively frequent among our interviewees; third, we defined the class category of families, according to the highest level by either spouse (rather than that of the male spouse). Class categories are identified by crossing the ten professional groups in the 2010 Classification with the professional situation of interviewees. In questionable cases, we used the level of education as a disambiguation criterion, according to the International Standard Classification of Education, 2011 (UNESCO 2012). 


\begin{tabular}{|c|c|c|c|c|c|c|c|c|c|c|c|c|c|c|c|c|c|c|}
\hline \multirow{3}{*}{$\begin{array}{l}\text { Class Category } \\
\text { of Family of } \\
\text { Origin }\end{array}$} & \multicolumn{18}{|c|}{ Class category of interviewee } \\
\hline & \multicolumn{2}{|c|}{ EO } & \multicolumn{2}{|c|}{ SM } & \multicolumn{2}{|l|}{$\mathbf{L P}$} & \multicolumn{2}{|l|}{ ISS } & \multicolumn{2}{|c|}{ MLTOP } & \multicolumn{2}{|c|}{ SEW } & \multicolumn{2}{|l|}{ SSP } & \multicolumn{2}{|l|}{ IW } & \multicolumn{2}{|c|}{ Total } \\
\hline & No. & $\%$ & No. & $\%$ & No. & $\%$ & No. & $\%$ & No. & $\%$ & No. & $\%$ & No. & $\%$ & No. & $\%$ & No. & $\%$ \\
\hline 1. $\mathrm{EO}$ & 2 & 25,0 & 1 & 12.5 & & 0.0 & 2 & 25.0 & 1 & 12.5 & 1 & 12.5 & 1 & 12.5 & & 0.0 & 8 & 100.0 \\
\hline 2. SM & & 0.0 & 6 & 17.7 & 10 & 29.4 & 5 & 14.7 & 2 & 5.9 & 5 & 14.7 & 6 & 17.7 & & 0.0 & 34 & 100.0 \\
\hline 3. LP & & 0.0 & & 0.0 & 7 & 63.6 & 3 & 27.3 & & 0.0 & & 0.0 & 1 & 9.1 & & 0.0 & 11 & 100.0 \\
\hline 4. ISS & 1 & 1.5 & 3 & 4.5 & 15 & 22.4 & 26 & 38.8 & 9 & 13.4 & 3 & 4.5 & 8 & 11.9 & 2 & 3.0 & 67 & 100.0 \\
\hline 5. MLTOP & & 0.0 & 2 & 10.0 & 2 & 10.0 & 6 & 30.0 & 5 & 25.0 & 2 & 10.0 & 2 & 10.0 & 1 & 5.0 & 20 & 100.0 \\
\hline 6. SEW & 1 & 4.8 & 3 & 14.3 & 7 & 33.3 & 2 & 9.5 & l & 4.8 & 2 & 9.5 & 2 & 9.5 & 3 & 14.3 & 21 & 100.0 \\
\hline 7. SSP & & 0.0 & 3 & 8.8 & 3 & 8.8 & 5 & 14.7 & 8 & 23.5 & 3 & 8.8 & 10 & 29.4 & 2 & 5.9 & 34 & 100.0 \\
\hline 8. SAO & & 0.0 & 1 & 100.0 & & 0.0 & & 0.0 & & 0.0 & & 0.0 & & 0.0 & & 0.0 & 1 & 100.0 \\
\hline 9. IW & & 0.0 & 3 & 18.8 & 3 & 18.8 & 3 & 18.8 & 2 & 12.5 & & 0.0 & 4 & 25.0 & 1 & 6.3 & 16 & 100.0 \\
\hline No data available & & 0.0 & 1 & 50.0 & l & 50.0 & & 0.0 & & 0.0 & & 0.0 & & 0.0 & & 0.0 & 2 & $100.0 \%$ \\
\hline Total & 4 & $1.9 \%$ & 23 & $10.8 \%$ & 48 & $22.4 \%$ & 52 & $24.3 \%$ & 28 & $13.1 \%$ & 16 & $7.5 \%$ & 34 & $15.9 \%$ & 9 & $4.2 \%$ & 214 & $100.0 \%$ \\
\hline
\end{tabular}

Table 7: Class categories of interviewees, according to class categories of families of origin (absolute figures and percentage) ${ }^{5}$

\section{Box 7: Edmundo, a descending social trajectory}

Edmundo is 40 years old and lives in Coimbra. He holds a high school diploma and is currently working as a qualified electrician. He considers that his attachment to punk ideals and lifestyle influenced, to some extent, his professional path. He claims to have always been seen as different in every company for which he worked. Even when he was the most obvious choice in technical terms, he was rejected for promotions, raises, and benefits. His parents belonged to the group of intellectuals and scientific experts, but he claims that this was never an advantage, even in a relatively small city like Coimbra. His professional life is commonly perceived
5 Although our total number of cases is relatively high (214), the crossing of two variables creates a matrix that, for many instances, includes no cases or very small numbers. In order to make a more sensible comparative analysis, we shall therefore combine some categories. 


\section{Box 8: Jaime, an ascending social trajectory}

Jaime is 43 years old and lives in Sintra. His parents are both industrial labourers who only completed primary school. He attended college but failed to obtain a degree. His professional life has always been connected to music, mostly in promotion. He worked for three different companies and is currently self-employed. He is responsible for the promotion of a concert venue in Lisbon. Within the Portuguese alternative scene, he is a leader in his segment and possesses high social and symbolic capital, as shown by his constant touring abroad with bands and constant invitations to run concert halls. This professional credibility led to his being consistently signalled by other interviewees as a key agent in the Portuguese punk scene, even though he does not identify as "punk"-an unmatched circumstance in our sample.
As for intergenerational class reproduction, it is naturally less intense in protagonists coming from lower-class families (the remaining 27 cases out of 72 , little more than one-third) than it is in the first two groups: $53 \%$ of the children of senior or middle-managers stick to one of those categories, as do $49 \%$ of the children of entrepreneurs, directors and liberal professionals.

In a nutshell, it comes across that, both when it comes to families and when it comes to their own current social position, the majority of interviewees-founders of or participants in the national punk scene-belong to middle and higher classes, associated with liberal professions, intellectual work, and technical expertise. Thus, the Portuguese case study corroborates current sociological distancing from the original representation of punk as a working class movement (cf. Bennett, 2001), but it particularly shows that one would fail to understand the movement's social bonds if they were reduced to one category. In this sense, it would be equally objectively incorrect and theoretically poor to classify punk as a working class subculture, just as it would be to classify it as a bourgeois or middle class subculture. The characterising trait-as is the case with other music scenes-is the crossing of diverse and often contrasting social trajectories and conditions: continuity in class (higher, middle, or lower), mobility trajectories that add nothing in particular to the global translation of society towards the reinforcement of the role and extension of middle classes, specific social ascending trajectories through professionalisation in or around music, and an important margin of descending intergenerational mobility, usually associated with a premature school dropout, experienced as social "downgrading." 


\section{Box 9: Lázaro, a trajectory of social reproduction}

Lázaro is 37 years old and lives in Guarda, a small city in the interior of Portugal. Having created several bands, he is a clear protagonist of Portuguese punk history, particularly when it comes to its manifestations outside Lisbon and Porto. He completed elementary education ( $9^{\text {th }}$ grade) and has since taken on multiple jobs: steel erector, steel fixer, labourer in a cable factory, employee at a gas pump, industrial worker in a factory of food products, and distribution agent of food products. At a moment of unemployment, he also benefited from public support to work in the Civil Protection services. Currently, he has been hired as a funeral assistant. Although he achieved a slight improvement in his educational capital (his parents only completed primary school), he replicates their socio-professional condition of unskilled, subordinate, precarious, and underpaid labour.

\section{Conclusion:}

\section{Studying the Social Condition of Punk in Its Diversity}

Dave Laing (2015) warns against the usual linking of British punk to the difficulties and aspirations of the working youth in times of economic crisis, stating that establishing that link can hide part of the true story. Although his sample is quite narrow (49 members of punk rock music bands), it suggests a social composition different from the one in Portugal: half of the musicians come from working classes, and the other half do not. This again suggests that the Portuguese punk scene's increased link to the high and middle classes is a result of its "imported" (and adapted) nature, requiring from early punk protagonists additional resources that allowed them to travel abroad and buy material. Our sample does have a strong diversity of profiles (includes musicians, mediators, and fans), as well as a larger number of interviewees. Still, Table 8 proves that there are no significant differences in social condition between the three main profiles.

Despite the differences, Portugal confirms Laing's (2015: 169) essential claim: "all the evidence is that the punk milieu was a heterogeneous and paradoxical one, something that might be expected to be reflected in class position and educational background also."

In an attempt to explain the heterogeneity, Laing invokes two factors: "the role of further (post-school) education and the unusual position in the class structure of professional musicians themselves" (Laing, 2015: 168). In fact, art schools in particular were important breeding grounds for alternative music callings-a bond quite well known in the United Kingdom and also present in 


\begin{tabular}{|c|c|c|c|c|c|c|c|c|}
\hline \multirow{3}{*}{ Class Category } & \multicolumn{6}{|c|}{ Profile of Interviewee } & \multirow{2}{*}{\multicolumn{2}{|c|}{ Total }} \\
\hline & \multicolumn{2}{|c|}{ Musician* } & \multicolumn{2}{|c|}{ Mediator } & \multicolumn{2}{|c|}{ Fan } & & \\
\hline & No. & $\%$ & No. & $\%$ & No. & $\%$ & $\mathbf{N .}^{\mathbf{0}}$ & $\%$ \\
\hline $\mathrm{EO}+\mathrm{SM}+\mathrm{LP}$ & 51 & 68,0 & 16 & 21,3 & 8 & 10,7 & 75 & 100 \\
\hline ISS + MILTOP & 58 & 72,5 & 11 & 13,8 & 11 & 13,8 & 80 & 100 \\
\hline SEW+ SSPIW & 39 & 66,1 & 10 & 16,9 & 10 & 16,9 & 59 & 100 \\
\hline Total & 148 & 69,2 & 37 & 17,3 & 29 & 13,6 & 214 & 100 \\
\hline
\end{tabular}

*(includes active and retired people, and those that accumulate being mediators or fans)

Table 8: Profile of interviewees, according to class category (\%)

the Portuguese case, particularly due to art secondary schools in Lisbon and Porto. Post-school training also provided leverage for musical performance-both amateur and professional-in which people coming from all different social classes converged.

When it does occur, the professionalising of work in music or connected areas, such as design, promotion and editing, or small commerce of records, costumes, and merchandise, leads to the positioning in the middle segments of the social space (middle class or "new petite bourgeoisie"). The working conditions, income, and prestige are quite different from those of the canonical "working class." But Laing stresses-as Hebdige had before-that this does not mean that there is no working class conscience, be it in terms of morality, politics, or lifestyle. This happens precisely because the relations between social condition and social representation, between a material position and the experience of the world, between life conditions and lifestyle, are not mechanical.
This is the core issue. As Albiez (2004) reiterates, punk must not be seen as a spontaneous expression of working class rage against the establishment. It was something slowly built and developed by a heterogeneous group of radicals, like Malcolm McLaren and Jamie Reid, art students, like Pete Shelley, talented young composers and musicians coming from the working classes, like John Lydon, or the high and middle classes, like Joe Strummer, and reporters and critics bored by the "accommodation" of rock. This process of creation of a new music movement and a new urban youth scene is complex and cannot be reduced to little more than mythical primordial attachments to a given social class (Laing, 1985; Redhead, 1993; Osgerby, 1998; Muggleton, 2000).

Does this mean that attention to the "social space" of origin and development of a culture like punk is dispensable? Of course not. Both the social space that allows for and favours the emergence and development of punk and the social space created and structured within punk-in Bourdieu's 
sense, the field-are inescapable elements for understanding that culture. In its origin, it is indivisible from the social and economic conditions of Great Britain and the United States in the I970s and the way they affect urban youth. As for Portugal, it would be difficult to explain its process of introduction and consolidation without reading into the political and social openness in the zos and 8 os and the way that newly acquired freedom was experienced by educated urban generations, belonging to working and middle class, and being involved in ascending, interrupted, or already-descending social trajectories (Pais, 2003; Guerra, 2010).

But first, the consideration of social space alone is not enough to understand the punk scene, which owes so much to the history of rock itself and to the challenges it faced in the final quarter of the $20^{\text {th }}$ century. And second, the characteristics of social position and condition that are truly meaningful and must be identified in order to analyse the social space are far from allowing mere mechanical imputations of behaviour to a given social origin. The social space of Portuguese punk can be better understood by highlighting how small and marginal it is, forcing the protagonists to polyvalence and taking on multiple roles; how male, urban, and suburban it is; how characterised it is by young generations whose ageing does not necessarily result in a complete severance from the cultural forms of adolescence, but rather, in the modulating of the references and roles adopted. It is best described as a space dominated by the relative accumulation of educational capital, but that also includes relevant segments of precocious school dropouts and social downgrading. And it is best described as a composite socio-occupational space, where different origins and class trajectories converge, cross, and influence each other. All of this, and all of the tensions that it originates, define Portuguese punk, in terms of social profile. 
Bibliography

Albiez Sean (2004), Punk after Punk: 1978-1984, online: http:// pt.scribd.com/doc/54282068/PunkAfter-Punk-1978-1984 [retrieved 05/07/2017].

Almeida João Ferreira de, Costa António Firmino da \& Machado Fernando Luís (1988), "Famílias, estudantes e universidade," Sociologia - Problemas e Práticas, $n^{\circ}$ 4, pp. 11-44.

- (1990), "Estudantes e amigos-trajectórias e redes de sociabilidade," Análise Social, n' 105-106.

Bennett Andy (2001), Cultures of Popular Music, Buckingham, Open University Press.

- (2004), "Consolidating the Music Scenes Perspective," Poetics, $n^{\circ} 32$, pp. 223 - 234.

- (2006), "Punk's Not Dead: the Continuing Significance of Punk Rock for an Older Generation of Fans," Sociology, vol. 40, n 2 , pp. 219-235.

- (2012), "Pour une réévaluation du concept de contre-culture," Volume! La revue des musiques populaires, vol. 9-1, pp. 19-31.

- (2013), Music, style and aging: growing old disgracefully? Philadelphia, Temple University Press.

Bennett Andy \& Richard A. Peterson (eds.) (2004), Music scenes: local, translocal and virtual, Nashville, Vanderbilt University Press.

Clarke John, et al. (1997), "Subcultures, Cultures and Class," in Ken Gelder \& Sarah Thornton (eds.), The Subculture Reader, London, Routledge, pp. 100-111.
Costa Pedro (2007), A cultura em Lisboa. Competitividade e desenvolvimento territorial, Lisboa, Imprensa de Ciências Sociais.

Crossley Nick (2015), Networks of Sound, Style and Subversion, Manchester, Manchester University Press.

Downes Julia (2007), "Riot Grrrl: the Legacy and Contemporary Landscape of DIY Feminist Cultural Activism," in Nadine Monem (ed.), Riot Grrrl. Revolution Girl Style Now!, London, Black Dog Publishing, pp. 12-51.

Fouce Héctor (2004), “El punk en el ojo del huracán: de la Nueva Ola a la Movida," Revista de Estudios de Juventud, $\mathrm{n}^{\circ} 64$, pp. 57-65.

- (2006), El futuro ya está aqui, Madrid, Velecíoeditores.

Frith Simon (1978), The Sociology of Rock, London, Constable.

Gelder Kenneth \& Thornton Sarah (1997), The Subcultures Reader, London, Routledge.

Gololobov Ivan (2014), "The

Evolution of Punk in Russia," in Ivan Gololobov, Hilary Pilkington \& Yngvar B. Steinholt (eds.), Punk in Russia. Cultural Mutation from the "Useless" to the "Moronic", London, Routledge, pp. 22-47.

Gololobov Ivan, Hilary Pilkington \& Yngvar B. Steinholt (eds.) (2014), Punk in Russia. Cultural Mutation from the "Useless" to the "Moronic", London, Routledge.

Gomes Rui Telmo (2013), Fazer música Underground: estetização do quotidiano, circuitos juvenis e ritual, $\mathrm{Ph}$.D. Thesis, online: http://hdl.handle.net/10071/6058 [retrieved 05/07/2017].

Greene S. (2012), "The Problem of Peru's Punk Underground:
An Approach to Under-Fuck the System," Journal of Popular Music Studies, vol. 24, n 4 , pp. 578-589.

Griffin Naomi (2012), "Gendered Performance Performing Gender in the DIY Punk and Hardcore Music Scene," Journal of International Women's Studies, vol. 13, $n^{\circ} 2$, pp. 66-81.

Guerra Paula (2010), A instável leveza do Rock: génese, dinâmica e consolidação do rock alternativo em Portugal (1980-2010), Ph.D.

Thesis, online: http://hdl.handle. net/10216/56304 [retrieved 05/07/2017].

- (2015), "Keep It Rocking: the Social Space of Portuguese Alternative Rock (1980-2010)," Journal of Sociology, vol. 51, n 1.

Guerra Paula \& Bennett Andy (2015), "Never Mind the Pistols? The Legacy and Authenticity of the Sex Pistols in Portugal," Popular Music and Society, DOI:10.1080/03007766. 2015.1041748

Hall Stuart \& Jefferson Tony (1976), Resistance through Rituals: Youth Subcultures in Post-War Britain, New York, Holmes \& Meier.

Hebdige Dick (1979), Subculture. The Meaning of Style, London, Methuen.

- (1997), "Subculture. The Meaning of Style," in Ken Gelder \& Sarah Thornton (eds.), The Subculture Reader, London, Routledge, pp. 130-142.

Hennion Antoine (2001), "Music Lovers. Taste as Performance," Theory, Culture and Society, vol 18, $n^{\circ} 5$, pp. 1-22.

Hodkinson Paul (2002), Goth: Identity, Style and Subculture, Oxford, Berg. 
Howes William Seth (2012), Punk Avant-Gardes: Disengagement and the End of East Germany, PhD Thesis, University of Michigan.

Humeau Pierig (2011), Sociologie de l'espace punk indépendant français: Apprentissages, trajectoires et vieillissement politico-artistique, Ph.D. Thesis, université Picardie Jules Verne.

Instituto Nacional de Estatística [INE] (2011), Classificação

Portuguesa das Profissões 2010, Lisboa.

Laing Dave (1985), One Chord Wonders: Power and Meaning in Punk Rock, Philadelphia, Open University Press.

- (2015), One Chord Wonders:

Power and Meaning in Punk Rock, Oakland, PM Press.

Martin-Iverson Sean (2014), "Running in Circles: Performing Values in the Bandung 'Do It Yourself' Hardcore Scene," Ethnomusicology Forum, vol. 23 , $n^{\circ} 2$, pp. 184-207. DOI:10.1080/17411 912.2014.926631

Mcrobbie Angela \& Garber Jenny (1997), "Girls and Subcultures," in Ken Gelder \& Sarah Thornton (eds.), The Subculture Reader, London, Routledge, p. 112-120.

- (1993), "Girls and Subcultures," in Stuart Hall \& Tony Jefferson (eds.), Resistance through Rituals: Youth Subcultures in Post-War Britain, London, Routledge.

Moreira Tânia (2013), Sons e lugares: trajeto e retrato da cena rock no Tâmega, MA Thesis, Porto, Faculdade de Letras da Universidade do Porto.

Muggleton David (2000), Inside Subculture. The Postmodern Meaning of Style, Oxford, Berg.
Muggleton David \& Weinzierl Rupert (2003), "What is 'postsubcultural studies' anyway?," in David Muggleton \& Rupert Weinzierl (eds.), The Post-Subcultures Reader, Oxford, Berg, pp. 3-23.

Nilan, Pam \& Feixa Carles (2006), Global Youth? Hybrid Identities, Plural Worlds, New York, Routledge.

O'connor Alan (2002), "Local Scenes and Dangerous Crossroads: Punk and Theories of Cultural Hybridity," Popular Music, vol. 21, $n^{\circ} 2$, pp. 225-237.

O'hara Craig (1999), The Philosophy of Punk: More than Noise, London, AK Press.

Osgerby Bill (1998), Youth in Britain since 1945, Oxford, Basil Blackwell.

Pais José Machado \& Blass Leila (eds.), (2004), Tribos urbanas. Produção artística de identidades, Lisbon, Imprensa de Ciências Sociais.

Pais José Machado (2003), Culturas juvenis, Lisbon, Imprensa Nacional Casa da Moeda.

Pereira Virgílio Borges, Pinto José Madureira \& Queirós João (2010), "Matriz de construção dos Lugares de Classe do Grupo Doméstico (considerando a possibilidade de pluriactividade e contemplando o cruzamento dos lugares de classe individuais do núcleo conjugal)," in José Madureira Pinto \& João Queirós (orgs.), Ir e Voltar. Sociologia de uma colectividade local do Noroeste Português, Porto, Afrontamento.

Pereira Virgílio Borges \&

Queirós João (2012), Na Modesta Cidadezinha. Génese e estruturação de um bairro de casas económicas do Porto (Amial, 1938-2010), Porto, Afrontamento.
Pilkington Hilary (2014), "Punk, but Not as We Know It: Rethinking Punk from a Post-Socialist Perspective," in Ivan Gololobov, Hilary Pilkington \& Yngvar B. Steinholt (eds.), Punk in Russia. Cultural Mutation from the "Useless" to the "Moronic", London, Routledge, pp. 1-21.

Reddington Helen (2012), The Lost Women of Rock Music, Sheffield, Equinox.

Redhead Steven (ed.), (1993), Rave off: Politics and Deviance in Contemporary Youth Culture, Aldershot, Avebury.

Rosen PaUl (1997), "It was Easy, It Was Cheap, Go and Do It!"

Technology and Anarchy in the UK Music Industry, York, University of York.

Sapiro Gisèle (1999), La guerre des écrivains, 1940-1953, Paris, Fayard.

Silva Augusto Santos \& Guerra Paula (2015), As palavras do punk, Lisbon, Alêtheia.

Simões José Alberto (2011), Entre a Rua e a Internet. Um estudo sobre o hip-hop português, Lisbon, Imprensa de Ciências Sociais.

Thornton Sarah (1996), Club Cultures: Music, Media and Subcultural Capital, Hannover, Wesleyan University Press.

UNESCO Institute for Statistics (2012), International Standard Classification of Education ISCED 2011, Canadá, UNESCO Publications, online: http://www. uis.unesco.org/

Verger Annie (1991), "Le champ des avant-gardes," Actes de la Recherche en Sciences Sociales, vol. $80, n^{\circ} 1$, pp. 2-40. 